\title{
PUBLIC HEALTH LEADERSHIP AND ITS IMPACT ON GLOBAL CRISES, ETHNIC AND RACIAL INEQUITY AND INEQUALITY IN HEALTH
}

\section{PRZYWÓDZTWO W ZDROWIU PUBLICZNYM ORAZ JEGO WPEYW NA KRYZYSY GLOBALNE, NIERÓWNOŚCI ETNICZNE I RASOWE ORAZ NIERÓWNOŚCI W ZDROWIU}

\author{
Amir Khorram-Manesh ${ }^{1,2(A, B, C, D, E, F)}$, Frederick M. Burkle ${ }^{3(E)}$, Krzysztof Goniewicz $^{4(A, D, E, F)}$ \\ ${ }^{1}$ Institute of Clinical Sciences, Department of Surgery, Sahlgrenska Academy, Gothenburg University, Sweden \\ ${ }^{2}$ Department of Development and Research, Armed Forces Center for Defense Medicine, Gothenburg, Sweden \\ ${ }^{3}$ Harvard Humanitarian Initiative, T.H. Chan School of Public Health, Harvard University, Boston, the United States \\ ${ }^{4}$ Department of Security Studies, Military University of Aviation, Dęblin, Poland
}

Authors' contribution Wkład autorów:

A. Study design/planning zaplanowanie badań

B. Data collection/entry zebranie danych

C. Data analysis/statistics dane - analiza i statystyki D. Data interpretation interpretacja danych E. Preparation of manuscript przygotowanie artykułu F. Literature analysis/search wyszukiwanie $i$ analiza literatury G. Funds collection zebranie funduszy

\section{Dear Editor,}

The responsibility for global public health crises and modelling for management are the responsibility of the World Health Organization (WHO) and the International Health Regulations Treaty (IHRT) and are delivered to and incorporated into all nations' national public health programs. However, implementation of public health policies at the national level depends on the public trust of the national authorities [1]. A trustful relationship is necessary for developing and maintaining the well-being of a community through various public health programs. The major aim of public health programs is to assess all risks, to identify underserved populations, and to initiate preventive measures, such as vaccines, social distancing, etc., through collaboration and coordination with other agencies and organizations, and considering all aspects of ethnic and racial equity, and equality of health [2].

These efforts require management authority, resources and financial support for public health and community research and sustainability of the changes they demand [1]. Public health management of infectious disease outbreaks and epidemics is very complicated and often politically heralded in the media for a short while, with the actual voices and advocates of success largely going unnoticed. Paradoxically, public health leaders and advocates have presently been facing a global pandemic with the world watching, judging, and criticizing their every move [3].

The key to success in public health crises lies in prevention, preparedness, vaccines, and control of infectious and environmental diseases. Developed countries expect public health to play a major role in managing outbreaks of infectious diseases and epidemics and as the prevalence of some diseases becomes high, health promotion strategies bring more resources and financial support to both local and global health resources. Societies rely on public health professionals who know how to utilize resources efficiently, creating, organizing and implementing a variety of public health strategies and programs for the benefit of the global population [4].

Keywords: public health emergency, healthcare disparities, Covid-19, leadership, disasters

Słowa kluczowe: krytyczne sytuacje w zdrowiu publicznym, nierówność w dostępie do służby zdrowia, Covid-19, przywództwo, katastrofy 
Nevertheless, one of the main obstacles for implementing public health policies and strategies is the increasing prevalence of health literacy in the world. Several reports from the US, Southeast Asian countries and Europe have indicated a low or limited global health literacy, resulting in worse healthcare and poorer health outcomes. In Europe, one in every two Europeans may not be able to comprehend essential health-related information and materials. This health literacy is consistently associated with several factors such as education, ethnicity and age. The lack of skills necessary to understand and manage their health does not allow active participation of these vulnerable groups in disease prevention programs [5].

The field of public health offers a multiagency and multi-professional collaboration that deals with populationbased health activities. The ongoing Covid-19 pandemic has been a valuable test for the governing bodies and has emphasized the significance of public health as a unique specialty and its leading role in appearing public health emergencies [6]. However, the current situation has also highlighted the significant role that a political and economic will may play in management of a global situation, when major public health decisions have frequently been highjacked by politics and economic demands $[1,4,5]$. In some countries, both economic and political leaders at state and national levels subsumed the leadership of public health decisions from the start, with many public health experts summarily being ignored, dismissed, or completely disregarded [3,4]. Many people live in a community that has lost its local public health department leadership during the coronavirus pandemic. Thus, losing the only hope for public education and overcoming public health literacy, and a voice for equity and equality in health, irrespective of race, ethnicity, and sexual orientation; creating a leadership vacuum in the profession [4]. The literature demonstrates studies on all 4 phases of disaster management cycle but there are a few if any that discuss why the work done in all phases does not improve the response to disasters and public health emergencies. The aim of this short review is to investigate the political, economic, public, and infrastructural factors that may influence the resiliency and response capacity of the disaster management system.

The future generation of public health leadership and authority, should have better training, and more respect to manage public health emergencies globally under a stronger and independent WHO [1,3]. It is evident that global public health emergencies will become more frequent in the future with accelerating climate changes, rapid urbanization, scarcities in food, water and energy resources, and deforestation to name but a few. These adversely influence all vulnerable groups, their rights, and the equity and equality in healthcare and demand public health professionals with focus on excellent communication and leadership skills [3] To fulfil their tasks, they require unmitigated authority to manage public health crises using improved quality of data, data analysis, forecasting, and infrastructure improvement, a strong focus on mitigating community-wide inequalities in race and sexual orientation and improved community resilience to move successfully through all phases of future pandemic and global public health challenges [3-5].

\section{References:}

1. Burkle FM Jr. Global health security demands a strong international health regulations treaty and leadership from a highly resourced World Health Organization. Disaster Med Public Health Prep. 2015; 9(5): 568-580. https://doi.org/10.1017/dmp.2015.26

2. Khorram-Manesh A. Flexible surge capacity-public health, public education, and disaster management. Health Promot Perspect. 2020; 10(3): 175-179. https://doi.org/10.34172/hpp.2020.30

3. Burkle FM, Devereaux AV. 50 states or 50 countries: what did we miss and what do we do now?. Prehosp Disaster Med. 2020; 35(4): 353-357. https://doi.org/10.1017/S1049023X20000746

4. Burkle FM Jr. Challenges of global public health emergencies: development of a health crisis management framework. TJEM. 2019; 249(1): 33-41. https://doi.org/10.1620/tjem.249.33

5. Khorram-Manesh A, Dulebenets MA, Goniewicz K. Implementing public health strategies - the need for educational initiatives: a systematic review. Int J Environm Res Public Health. 2021; $18(11)$ : 5888. https://doi.org/10.3390/ijerph18115888

6. Goniewicz K, Carlström E, Hertelendy AJ, Burkle FM, Goniewicz, M, Lasota D, et al. Integrated healthcare and the dilemma of public health emergencies. Sustainability. 2021; 13: 4517. https://doi.org/10.3390/ su13084517 